\title{
OPINIONS OF VETERAN RUNNERS ON THE INFLUENCE BETWEEN LONG-DISTANCE RUNNING AND HOLISTICALLY INTERPRETED HEALTH
}

\section{Josef Oborný \\ Department of Sport Educology and Sport Humanities, Faculty of Physical Education and Sport, Comenius University in Bratislava}

Summary: The objective of the research was to determine the cognitive basis, the classification and evaluation of the long experience of long-distance runners in the senior category in relation to the perception of running as a factor in their overall health and wellbeing. Research was conducted with a sample of male and female long-distance runners with long experience in domestic and foreign longdistance running events in veteran categories. Oral and written interviews with the same questions were used to acquire information on the correlation between holistically understood health and long-term participation in long-distance running. The interview design allowed respondents to express their opinion on the questions in more detail through additional notes. A quantitative analysis of the acquired data was conducted using standard mathematical operations and the incidence of responses in percentage terms. The hypotheses were tested using a test on the parameter $p$ of a binomial distribution and a median test. Senior-age long-distance runners' decision to take up running was found to have both heteronomous motivation (encouragement by a sports teacher, admiration for other runners, persuasion by colleagues) and autonomous motivation (an internal need to run, a means for overcoming mental stress and restoring internal balance, the need to lose weight, elimination of health problems, the desire to compete). The majority of runners agreed that long-distance running had a positive effect on their overall health and physical condition. Long-distance runners rated the effect of long-distance running on their social and personal wellbeing to be greater than three on a five-point scale did. There is no statistically significant difference between the number of runners who think that long practice of running has some negative effects on their health and the number of runners who think that it has no negative effects. The majority of runners think that their health is better than that of their peers who do no sport.

Key words: runners of senior age, motivation for running, social and personal wellbeing 


\section{Introduction}

Before starting research, we defined following research problem. The effect of longdistance running as a lifelong sport activity on the holistically understood health of the runner. We decided to study this issue by consulting the opinions of long-distance runners with decades of experience in this kinetic sport activity. The long personal experience of sports participants is vital in many areas of sports research. There is also much that can be learned from the experience of other authors and current runners. One of these has said that running, in particular long-distance running is the universal, most accessible and most widely practised sport on our planet (Finn, 2012).

\section{Aim}

The objective of the research was to determine the cognitive basis, the classification and evaluation of the long experience of long-distance runners in the seniors' category in relation to the perception of running as a factor in their overall health and wellbeing.

\section{Characteristics of the research sample}

In general terms our research sample can be seen as a set of individuals, a community that "considers itself to be only an aggregate of individuals" (Černík \& Viceník 2011). In preparing our research sample, we respected the requirement of the research method (an oral and written interview) and sought a set of respondents that we expected to be able and willing to engage in a dialogue and tell their story. In this regard, the research benefited from the fact that the researcher knew all the consulted respondents in person, had personal experience of recreational and competitive long-distance running and was an authentic participant in running events. Our research sample was made up of male and female long-distance runners with long experience in domestic and foreign long-distance running events in the veteran category. The majority of respondents have rich experience of large international running events. The research sample was created by a guided but spontaneous selection based on the researcher's personal knowledge of the structure of runners in the relevant age group. The respondents come from various regions of Slovakia. The information database for the selection of respondents was also drawn from the lists of runners registered for large running events such as the $11^{\text {th }}$ ČSOB Bratislava Marathon 2016 and the Košice Peace Marathon 2016. The sample is described more detailed in the results section.

\section{Research hypotheses}

H 1. Runners of senior age started running based on heteronomous motivation. 
H 2. The majority of runners agree that long-distance running has a relevant positive effect on their health and wellbeing.

H 3. The majority of long-distance runners rated the effect of long-distance running on their social and personal wellbeing to be greater than three points on the five-point scale.

$\mathrm{H} 4$. The majority of runners consider their health incomparably better than that of their peers.

H 5. The majority of runners consider negative effects of long-distance running on their health to be non-existent.

\section{Methods}

The sample comprised 16 men and 2 women. The average age of the men was 64.4 years and they had an average of 35.3 years of running experience. They ran on average 3.7 marathons and 6.5 half marathons per year, their average personal best times in marathons being just under 3 hours (Table 1). The women's average age was 63 years and they had been running for an average 34.5 years. Their average totals for active runs was 7 marathons and 5 half marathons per year with an average personal best over marathon distance of just over 3 hours.

Table 1

Characteristics of the research sample by sex

\begin{tabular}{|l|l|l|}
\hline & Men (N = 16) & Women (N = 2) \\
\hline Age & $64.38(4.13)$ & $63.00(7.07)$ \\
\hline Number of years as a runner & $35.33(12.75)$ & $34.50(2.12)$ \\
\hline Number of marathons per year of running & $3.73(3.17)$ & $7.02(4.38)$ \\
\hline Number of half marathons per year of running & $6.52(5.99)$ & $5.02(2.81)$ \\
\hline Best time in a marathon & $02: 55: 30$ & $03: 03: 28$ \\
\hline Best time in a half marathon & $01: 28: 02$ & $01: 29: 25$ \\
\hline
\end{tabular}

(the number before the bracket represents the average value of the variable for the respondents who answered the question; the number in brackets is the standard deviation)

\section{a. Method used to collect research data}

The first stage of the project was to elaborate the research procedure. Following Ochrana (2009), we understand a research procedure as a "procedure that gradually implements a defined task related to research and the achievement of the research objective". Our research uses the methodological principle of individualism - attention is focussed on the individual and the community of runners is seen as merely an accumulation of individuals. It ignores the existence of certain units above the level of the individual. De facto, all runners 
run only for their own benefit Units above the level of the individual in this area of research could include, for example, long-distance relay races. Holism (research focussed on a particular social unit such as a "sport" group, e.g. the group of all long-distance runners) and systemism (aimed at providing an adequate account of the interaction between the individual and society, or the community of runners) were excluded from the approach.

Our research applies a principle that tries to reflect most adequately the interaction between the runner as an individual and the community of runners. To do this, data was collected on the correlation between holistically understood health and long-term participation in long-distance running through oral and written interviews. It is analogical to a questionnaire completed ad hoc with the possibility to record additional comments. A submethod of this interview is the method of the additional comment, which allows interviewed runners to express their views in line with the question but also to step outside the set boundaries to some extent. Gavora (2007) and Hendl (2005) call this type of qualitative research a narrative interview.

\section{b. Method used to evaluate the obtained data}

The used to evaluate the data that our research yielded reflects the size of the sample, the degree of homogeneity in the sample and, naturally, the research objective. The sample did not include a very large number of respondents but included a relatively large percentage of the men and women who are active in the sport with long years of experience. The low robustness of the sample is therefore not a handicap for research (Volín 2007). A quantitative analysis of the acquired data was conducted using standard mathematical operations and the incidence of responses in percentage terms. The hypotheses were tested using a test on the parameter $p$ of a binomial distribution and a median test. The acquired data is interpreted by means of verbal commentary and also tables, illustrations and the runners' own interpretation in the form of their supplementary statements.

\section{Results and discussion}

Hypothesis $\mathbf{H 1}$ (runners of senior age started running based on heteronomous motivation) was tested by the answers of respondents to item 6 in the questionnaire. This asked respondents why they took up running. Seven respondents stated that they took up running because of an internal need for movement to run. The other eleven runners mentioned 
heteronomous reasons. They began running based on encouragement by a teacher or friends, to improve their physical condition or health. These reasons can be classified as heteronomous or autonomous. We wanted to determine whether the proportion of respondents who gave heteronomous reasons was statistically significantly greater than the proportion of respondents who mentioned autonomous reasons. Significance can be tested using a test on the parameter $\mathrm{p}$ of a binomial distribution where $\mathrm{p}$ is the proportion of respondents with heteronomous motivation. The statistical hypothesis $H_{0}: p=1 / 2$ was tested against the alternative hypothesis $H_{1}: p>1 / 2$. with a significance level of 0.05 . The resulting $\mathrm{p}$ value was 0.240 , which is above the selected significance level of 0.05 , which means that there is no reason to reject the null hypothesis, which is that there is no statistically significant difference between the number of respondents reporting heteronomous and autonomous motivation. The reader can compare these results with our findings in earlier research on this issue (Oborný 2015a). The following table shows the runners' authentic comments on this item.

\begin{tabular}{|l|l|}
\hline Runner & \multicolumn{1}{|c|}{ Why did you take up running? What is your motivation for running? } \\
\hline M01 & Two basic reasons: to stop feeling restless; to go out for fresh air \\
\hline M02 & $\begin{array}{l}\text { Internal body need to run. Running became a way to fight stress. Now it is like an addiction } \\
\text { to running. When I was a child, my older sister and my PE teacher encouraged me to do } \\
\text { sport. }\end{array}$ \\
\hline M03 & I was "made" to run by a teacher at secondary school and I got into it. \\
\hline M04 & To get myself into shape \\
\hline M05 & Because I felt like I was not getting enough movement and I started to put on weight. \\
\hline M06 & $\begin{array}{l}\text { I had always done sport, since I was a child. I did sport for my own reasons. I enjoyed it! } \\
\text { Physical education lessons in basic school had a good influence on me. }\end{array}$ \\
\hline M07 & At first, I was worried about my weight and later I just enjoyed moving. \\
\hline M08 & $\begin{array}{l}\text { I stopped playing football regularly, I was not getting enough movement and I started to put } \\
\text { on weight. }\end{array}$ \\
\hline M09 & Competitiveness, physical condition, individual attitude towards running. \\
\hline M10 & $\begin{array}{l}\text { I already ran when I was a boy. I started running systematically (keeping records) to } \\
\text { improve my health after a stomach operation in 1981. Overall, my records show I've run } \\
\text { over 115,000 km. }\end{array}$ \\
\hline M11 & Therapy for health problems \\
\hline M12 & I needed movement because I have the sort of job where you sit a lot. \\
\hline M13 & $\begin{array}{l}\text { Compensation for stress (I teach maths and geography in basic school); getting to know } \\
\text { Slovakia, health }\end{array}$ \\
\hline M14 & I wanted to do a marathon and then I started to enjoy running and now I run all the time. \\
\hline M15 & $\begin{array}{l}\text { I had always admired runners and one time they asked me if I wanted to join them; I started } \\
\text { and I have never stopped. Motivation: I get to meet good friends, enjoy a good feeling and } \\
\text { relax. }\end{array}$ \\
\hline M16 & Mainly because I had some health problems that I wanted to get rid of. \\
\hline W1 $\ldots$ Motivation? None ... I just went running, then I started to win races and I liked it... It was \\
\hline
\end{tabular}




\begin{tabular}{|l|l|}
\hline & $\begin{array}{l}\text { a different time, but later, running helped me to deal with disappointments..., I was able to } \\
\text { think about my work while I was running..., at races, I met people and improved my social } \\
\text { life. }\end{array}$ \\
\hline W2 & $\begin{array}{l}\text { I started working at a place where a lot of my colleagues were runners and they persuaded } \\
\text { me that I should run to work with them. It was about } 15 \mathrm{~km} \text { from home, so that laid the } \\
\text { foundation. I won a company running race without any training. I also liked all sorts of } \\
\text { movement. I also have particular motivation from my current husband who I had met in } \\
\text { these competitions and he is still doing sports. }\end{array}$ \\
\hline
\end{tabular}

$\mathrm{M}$ - man; W - woman

Gotaas (2008) have described the historical, anthropological and contemporary modern motivation for people to run as follows: "Modern runners are imitating something that our ancient ancestors did to win the battle for survival. Nowadays we run "for our lives" in a different way, but it is just as human because it makes us feel a lot better and it acts as a counterweight to our sedentary lifestyles. Runners rarely think about it, but they are moving like our ancestors in Africa, when they ran across the savannah for their lives - just like Kenyans do now" (Gotaas, 2008).

Hypothesis $\mathbf{H 2}$ (the majority of runners agree that long-distance running has a relevant positive effect on their health and wellbeing) was tested based on the responses of the respondents to item 7 on the questionnaire, to which 16 (89\%) of the respondents replied that "without running I would certainly have a much lower level of health and wellbeing at my age" or "running has certainly improved my social life and health" and two of them gave a different answer ("I cannot judge" or "other"). The responses to the question can thus be either classified as a positive effect of running on overall health and wellbeing or other. We wanted to determine whether the proportion of respondents who referred to a positive effect of longdistance running on overall health and wellbeing was statistically significantly higher than the proportion of respondents giving another type of answer. Significance was tested using a test on the parameter $p$ of a binomial distribution where $p$ is the proportion of respondents reporting a positive effect. The statistical hypothesis $H_{0}: p=1 / 2$ was tested against the alternative hypothesis $H_{1}: p>1 / 2$. with a significance level of 0.05 . The resulting $p$-value was less than 0.001 , which is below the chosen significance level 0.05 , and therefore the null hypothesis was rejected, leading to the conclusion that the majority of runners believe that long-distance running has a positive effect on their overall health and wellbeing.

Additional comments that respondents provided for this question: 
M01: In $99 \%$ of my runs, I felt $100 \%$ better when I finished than I did before the run and I still feel this way today.

M06: I saw running as a source of interesting experiences and a way to strengthen my health. For example, in 1985 I ran my first marathon (Považie Marathon in Nové mesto nad Váhom) and during the race there was a heavy downpour and so much rain fell that you could not see the road. Cars were stopping and the drivers were shouting, "We'll give you a lift"! However, by the time we got to the finish line, we were all dry because the weather had changed completely. Another experience was the 1985 Košice Peace Marathon - an incredible heatwave; we drank water from the spectators; there was a limit of 4 hours and 200 runners dropped out; that was the best test of a runner's overall personality.

M09: Running has definitely been good for my health and my social life.

M10: People sometimes stop me when I am running and ask how old I am and whether my knees do not give way and stuff like that.

Hypothesis $\mathbf{H 3}$ (the majority of long-distance runners rated the effect of long-distance running on their social and personal wellbeing to be greater than three on a five-point scale) item 8 of our questionnaire, Can you assess the specific effect on long-distance running on your health?, covered three areas, which the respondents assessed on a scale of $0-5$ as follows: Bodily health $-93 \%$ chose options 4 or 5 , and one of the respondents was a doctor; Mental health, life without neuroses $-75 \%$ chose options 4 or 5 and one of the respondents was a doctor. The active long-distance runner Jurek (2012) has also commented on this topic: "If you want to be a runner, all you have to do is go to the forest or go out on the street and start running. Even 50 metres is enough, if you cannot manage more. Tomorrow you will go further. Movement will make you happy and give you instinctive pleasure. You will feel like you are playing, which is how it should be." Hypothesis H3 was nevertheless tested based on the respondents' relating to social and personal wellbeing, where respondents commented on the influence of long-distance running in this area (Figure 1). 


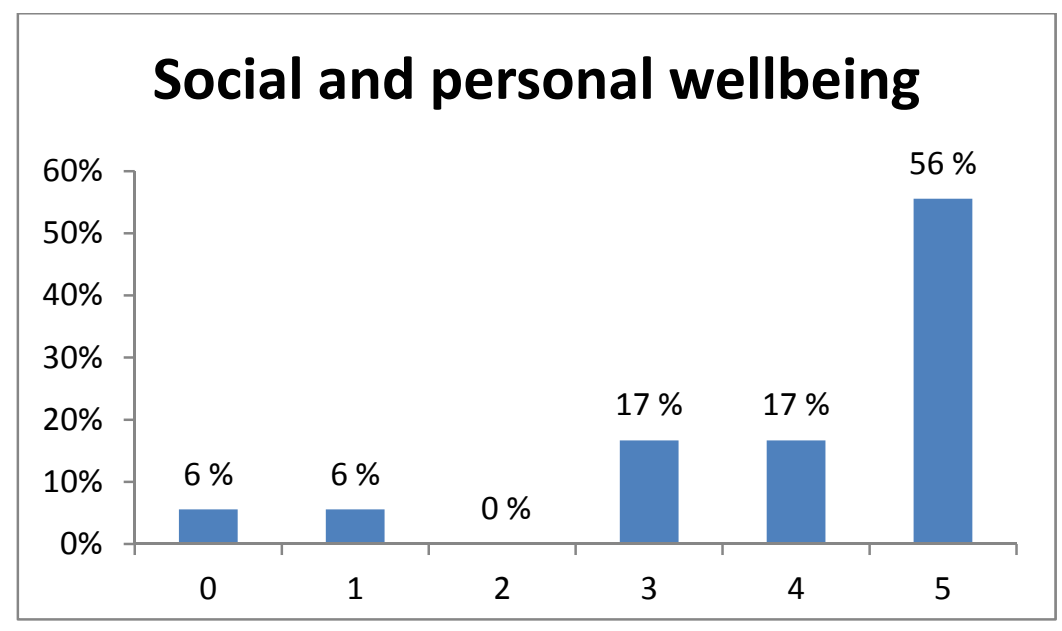

$(0$ - no effect; 5 - a very strong positive and vital effect)

Figure 1

The bar graph shows the effect of long-distance running on social and personal wellbeing

Whether the effect of long-distance running on social and personal wellbeing was greater than 3 was assessed by means of a median test. The statistical hypothesis $H_{0}: \overline{\bar{x}}=3$ is tested against the alternative hypothesis $H_{1}: \overline{\bar{x}}>3$, where $\overline{\bar{x}}$ is the median. The value of the test statistic $T=13$ is greater than the critical value for the one-sided alternative based on a significance level of 0.05 , which is 9 , and therefore the null hypothesis is rejected in favour of the alternative hypothesis. Long-distance runners rate the effect of long-distance running on their social and personal wellbeing to be greater than three on the given scale. In this case, the doctor chose level 3. The results are in line with other research conducted by the author (Oborný 2015b).

\section{Additional comments of the respondents to this question:}

Note: respondents also commented the sub-item Bodily health.

M02: Above all, a more robust cardiovascular system. The doctors have mentioned this several times when I went for preventive medical checkups.

M06: I have had leg injuries, but no illnesses.

M08: As I see it, mental health and social and personal wellbeing are primarily a question of feeling comfortable and having good relations with those around me (family and friends).

Hypothesis $\mathrm{H4}$ (the majority of runners consider their health to be incomparably better than that of their peers) was tested using the respondents' answers to item 10 on the questionnaire, where $6(33 \%)$ said that their health condition is better, $10(56 \%)$ said that it is incomparably better and $2(11 \%)$ said that they could not judge. In total, 16 respondents (89\%) think that their health is better than that of their peers. We wanted to determine 
whether the proportion of respondents who said that their health is better than that of their peers was statistically significantly higher than the proportion of respondents giving another type of answer. Significance was tested using a test on the parameter $p$ of a binomial distribution where $p$ is the proportion of respondents reporting better health. The statistical hypothesis $H_{0}: p=1 / 2$ is tested against the alternative hypothesis $H_{1}: p>1 / 2$. with a significance level of 0.05 . The resulting $p$-value is less than 0.001 , which is below the chosen significance level 0.05 , and therefore the null hypothesis is rejected in favour of the alternative hypothesis. The majority of runners think that their health is better than that of peers who do no sport. The doctor who responded chose the response Health is better.

\section{Additional comments that respondents provided for this question:}

M02: I cannot judge it for all my peers. Some of them have already died, unfortunately.

M06: The people who do not do sport get tired faster (I mean, my former colleagues); they always make time for smoking, and we all know how that finishes.

M08: All of us have some sort of little pain at our age, and not everyone wants to boast about their health.

M10: I meet young people more often than I meet my peers.

Hypothesis $\mathbf{H 5}$ (the majority of runners consider negative effects of long-distance running on their health to be non-existent) was tested using the respondents' responses to item 12 of the questionnaire, which was assessed using a scale from 0 to 5.

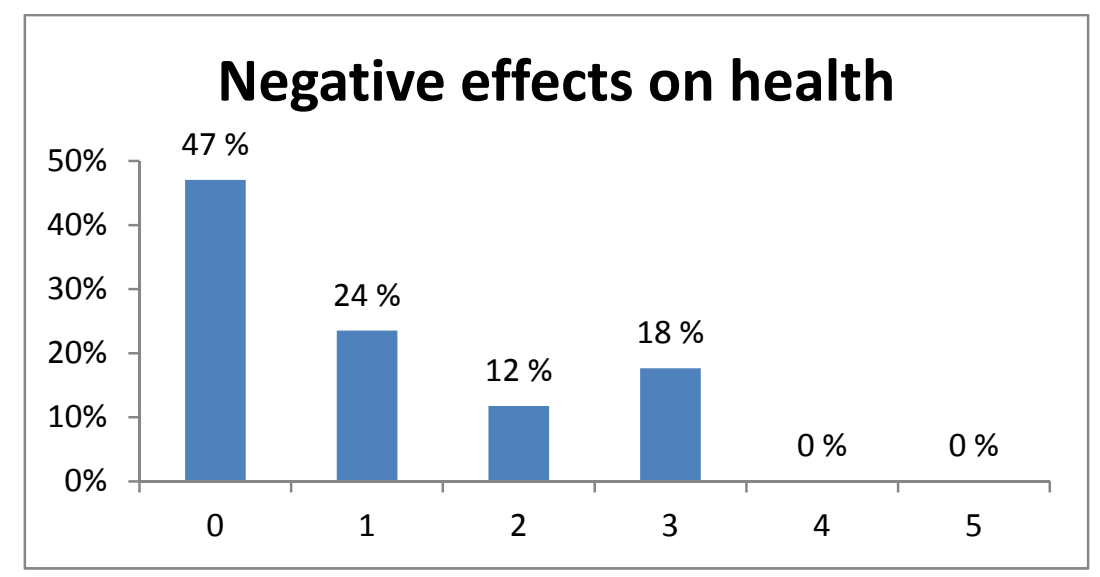

$(0$ - no negative effect on health, 5 - long experience of running has had a negative effect on my health)

Figure 2

Bar chart of the effects of long-distance running on health 
A total of 9 respondents ( $53 \%$ ) thought that running could have a negative impact on their health and the remaining $47 \%$ of respondents thought that there was no negative effect. The doctor who responded chose level 2 on the scale. We wanted to determine whether the proportion of respondents who thought that long practice of running had not had a negative effect on their health was statistically significantly higher than the proportion of respondents who though running could also have a negative effect on their health. Significance was tested using a test on the parameter $\mathrm{p}$ of a binomial distribution where $\mathrm{p}$ is the proportion of respondents thinking that long practice of running had no negative effect on their health. The statistical hypothesis $H_{0}: p=1 / 2$ was tested against the alternative hypothesis $H_{1}: p>1 / 2$. with a significance level of 0.05 . The resulting p-value was 0.761 , which is above the chosen significance level 0.05 , and therefore the null hypothesis is not rejected. There is no statistically significant difference between the proportion of runners who think that long practice of running has some negative effects on their health and the number of runners who think that it has no negative effects. On the other hand, here is a view from the other side: "Eight out of ten runners suffer an injury every year. It doesn't matter whether you are fat or thin, fast or slow, whether you have won a marathon or you get running fever only occasionally - the probability that you will wreck your knee, shin, tendons, hips or heels is the same for everyone" (McDougall 2010).

Our research also inquired about what motivated veteran long-distance runners to run. Respondents had to look back decades when they wanted to answer this question. We have left the content of their answers in their authentic state. Only a few formal corrections have been made to the text.

\section{Additional comments that respondents provided for this question:}

M02: Even a recreational runner still runs the risk of injury. However, I do not know about any other negative health effects of running.

M06: It is important for runners to go for preventative medical check-ups and consult with a doctor, especially as they get older.

M08: If a run (or a race) is well matched to your age and health condition, and your organism's level of training, there should not be any problems. On the other hand, old injuries from youth (football, hockey and other youthful activities) might pop up again.

M09: Besides intensive training, there has been hard physical work in the garden, timeconsuming work as a designer and very little sleep, and they have all taken a toll on my health. 
M10: Sometimes I fall down and get a bruise; a couple of times I have pulled a muscle and so on.

\section{Recommendations for persons interested in taking up running}

(This is based on an item with the following instructions: We would like to give you space to express any other opinions you have on running. For example, is there something you would like to say to young participants in sports?).

\begin{tabular}{|c|c|}
\hline Runner & $\begin{array}{l}\text { Some opinions on running. For example, is there anything you would like to say to } \\
\text { young participants in sports? }\end{array}$ \\
\hline M01 & $\begin{array}{l}\text { First of all, I do not like comparing myself to other people who run, I like to compete with } \\
\text { them (as long as I have a chance). You could write whole books about running and many } \\
\text { books have been written, but I will say a couple of words - just that running is amazing, } \\
\text { amazing, amazing... try it and you will see. }\end{array}$ \\
\hline M02 & $\begin{array}{l}\text { Run! It is a sport, or a movement activity that is for everyone. Whatever other sport you } \\
\text { do, you need it to keep in shape. Running is a faster way to get to know a new } \\
\text { environment. Running has enabled me to get to know several of the main cities in Europe. } \\
\text { What's more - running is not a seasonal sport; you can run all year round in any weather. } \\
\text { Just make sure you have the right shoes and clothes. Run by yourself or with a kindred } \\
\text { spirit. Act in a pro-social way at the big events - your "life" does not depend on it, just } \\
\text { enjoy it. I hope to see you at one of our running events. }\end{array}$ \\
\hline M03 & $\begin{array}{l}\text { Listen more to your body and less to your trainer, because all they want is to "force" you } \\
\text { to give a better performance no matter the cost... }\end{array}$ \\
\hline M06 & $\begin{array}{l}\text { For my first ultramarathon, I trained around } 120 \mathrm{~km} \text { per week. I recommend you to sign } \\
\text { up for an ultramarathon after } 30 \text {, not sooner. Do not underestimate your clothing and } \\
\text { choosing the right footwear for the weather and the route. Eat food } 2 \mathrm{~h} \text { before and } 2 \mathrm{~h} \text { after } \\
\text { running. Dietary supplements (for joints or higher performance) did not work out for me. } \\
\text { It is important to stretch before and after running, at least } 15 \text { minutes. Do not enter } \\
\text { marathons without training (just to show off). It took me } 3 \text { years to train for my first } \\
\text { marathon. It does not pay to be impatient - you might not feel the bad effects straight } \\
\text { away. If you want to do well in sport, you have to create healthy living conditions, have a } \\
\text { healthy life routine (!) and then develop a healthy lifestyle. Do not go into races with } \\
\text { headphones on. }\end{array}$ \\
\hline M07 & $\begin{array}{l}\text { Do not give up; follow your ambitions; do not be lazy - training and a strong will make } \\
\text { everything easier. }\end{array}$ \\
\hline M08 & $\begin{array}{l}\text { In the fast-paced lives we live nowadays, it is important to find times for ourselves and } \\
\text { regenerate our physical, and in particular our mental condition, and why not do this by } \\
\text { going for a run in the fresh air? This can work wonders; just try it and you will see. Not all } \\
\text { of us want to be world champions. }\end{array}$ \\
\hline M09 & $\begin{array}{l}\text { Do not run when you're injured, when you have a high temperature or the flu, when you } \\
\text { are taking antibiotics, take care of your teeth, change sweaty clothes as soon as you can, } \\
\text { do complementary exercises and regeneration regularly, get the sleep you need, a varied } \\
\text { diet, have a complete medical check-up from time to time. }\end{array}$ \\
\hline M10 & $\begin{array}{l}\text { There is no doubt that running is a good activity in life. It gives life another meaning, } \\
\text { increases self-respect, helps to prevent various ailments: colds, varicose veins, }\end{array}$ \\
\hline
\end{tabular}




\begin{tabular}{|c|c|}
\hline & $\begin{array}{l}\text { cardiovascular disease, stress and the like. I personally have nearly forgotten that I went } \\
\text { for an operation on my stomach (in 1981). However, I have to add that a healthy diet and } \\
\text { dietary supplements (vitamins, minerals and the like) also have an important part to play. } \\
\text { For myself, I take natural supplements from Nutrilite. What is my message to young } \\
\text { people? If you want to run, it is very good idea to prepare a running part of your schedule, } \\
\text { at least 2-3 times per week. It will give you a very good return. }\end{array}$ \\
\hline M11 & $\begin{array}{l}\text { Running is an addiction: it does not matter whether I feel like it; I just have to do it. I } \\
\text { organise my whole daily routine around it, including meals and rest. When I started, } \\
\text { people used to laugh at me. Now I laugh at people who feel bad and get nervous about it. } \\
\text { Running makes sense over the long term. }\end{array}$ \\
\hline M13 & $\begin{array}{l}\text { Nowadays, young people have a lot more information than we had about running and } \\
\text { everything connected with it; they can get health checks, the equipment is of a high } \\
\text { standard, there are personal trainers (specialists) available... use them to achieve your } \\
\text { objectives. }\end{array}$ \\
\hline M14 & $\begin{array}{l}\text { Running as a sport activity has saved my life twice: when there was an industrial gas } \\
\text { poisoning at the East-Slovak Steel Works and when I had a stroke in 2013, and that is why } \\
\text { I will never give up running. }\end{array}$ \\
\hline M15 & $\begin{array}{l}\text { Young people should not be ashamed to join us; they should not let themselves be put off } \\
\text { by their peers or a weak performance. Anyone who runs is always better than someone } \\
\text { who criticises and tries to stop him or her running. It doesn't matter if your slower than } \\
\text { older runners; not everyone is built to win; your already a winner when you make yourself } \\
\text { do sport. }\end{array}$ \\
\hline M16 & $\begin{array}{l}\text { I have done many different sports in my life - cycling, hiking, mountaineering but nothing } \\
\text { has given me as much pleasure as running. That is why I would heartily recommend } \\
\text { anyone who was looking for a sport to last a lifetime, or people who want to lose weight, } \\
\text { to take up running - a slow, persistent run forever. One more thing to mention, "less is } \\
\text { more than doing nothing", do not overdo your pace and do not forget that your legs must } \\
\text { hit the surface softly. Wishing you good luck in all your runs, Miro. }\end{array}$ \\
\hline W1 & $\begin{array}{l}\text { No, everyone is different, unique and responsible for him or her... which is why everyone } \\
\text { needs to know what is best for him or her. One thing that I do know and which I am very } \\
\text { happy about is that my daughter and son both took up running as adults (not sport - they } \\
\text { already did that as children), they found out that they enjoy running, although I think it's } \\
\text { connected with the modern running "boom"... }\end{array}$ \\
\hline W2 & $\begin{array}{l}\text { Never stop doing sport. Keep on doing a sport, even if not taking part in races - as long as } \\
\text { your health allows. }\end{array}$ \\
\hline
\end{tabular}

Experience runners know that running is part of their life, that running is also about "struggle" and suffering. In this context, it is recommended, particularly to people starting out in running, to read specialised literature on this topic, especially works written in narrative style (as a story) or as essays (Bielik 2014).

\section{Conclusion}

All the respondents are active long-distance runners and take part in organised running competitions. They have been running for decades; they are aged over 60 and have rich 
experience of life and sport. Their opinions are relevant for the area of research. The respondents' motivation to run can be found in their external environment, but also in the runner's subjective personality. The proportion of respondents who gave heteronomous reasons was not statistically significantly different from the proportion of respondents who mentioned autonomous reasons. The majority of runners said that long-distance running had a positive effect on their overall health and physical condition. They also agreed that the relationship between running and their health was that "without running I would certainly have incomparably worse health and wellbeing at my age".

The majority of runners think that their health is better than that of their peers who do no sport. There is no statistically significant difference between the proportion of runners who think that long practice of running has some negative effects on their health and the number of runners who think that it has no negative effects. The option "no negative impact on my health" was chosen by $44 \%$ of the respondents. Most of the responses to this question were self-critical. Runners do not idealise their sport. It can be said that the respondents approached the survey in a responsible manner.

\section{Acknowledgement}

This contribution addresses a part of the subject-matter of the research project "Historical and structural changes in the development of sport in the 20th century and their impact on the attitudes of different generations of Slovak population to sport and to take up sport", VEGA No 1/0268/16.

\section{References}

1. BIELIK, V., 2014. Umenie behat'. Senec: Sportdiag team, o. z. ISBN 978-80-970342-1-4.

2. ČERNÍK, V. \& J. VICENÍK, 2011. Úvod do metodológie spoločenských vied. Bratislava: IRIS. ISBN 978-80-98256-79-2.

3. FINN, A., 2012. Running with the Kenyans: Discovering the secrets of the fastest people on earth. Faber and Faber. ISBN-13:978-0345528803.

4. GAVORA, P., 2007. Metodológia kvalitatívneho výskumu. Bratislava: Vydavatel'stvo Univerzity Komenského. ISBN 978-80-223-2307-8.

5. GOTAAS, T., 2008. Løping, En verdenshistorie. Oslo: Gyldendal Norsk Forlag AS.

6. HENDL, J., 2005. Kvalitativní výzkum. Základní metody a aplikace. Praha: Portál. ISBN 80-7367-040-2.

7. JUREK, S., 2012. Eat \& Run. My Unlikely Journey to Ultramarathon Greatness. New York: Houghton Mifflin Harcourt.

8. MCDOUGALL, Ch., 2010. Born to Run. New York: Alfred A. Knopf. 
9. OBORNÝ, J., 2015a. Filozofia a šport. Bratislava: Vydavatel'stvo Univerzity Komenského. ISBN 987-80-223-3659-7.

10. OBORNÝ, J., 2015b. Reflexia pohybu a zdravia $\mathrm{v}$ súčasnej športovej kultúrnej antropológii (Reflections of movement and health in the current cultural anthropology of sports). In: Zdravotnicke listy. Scientific peer-reviewed journal. 3(3). ISSN 1339-3022.

11. OCHRANA, F., 2009. Metodologie vědy. Úvod do problému. Praha: Karolinum. ISBN 978-80-246-16094.

12. VOLÍN, J., 2007. Statistické metody ve fonetickém výzkumu. Praha: Nakladatelství EPOCHA. ISBN 978-80-87027-54-7. 